\title{
Proceeding
}

Supplementary Issue: Spring Conferences of Sports Science. Costa Blanca Sports Science Week, 26-28 April 2018. Calpe. Alicante, Spain

\section{Effectiveness indices evaluating time in physical education: Example in Motor Games}

PEDRO A. VALDIVIA-MORAL 14 , ANDRÉS B. FERNÁNDEZ-REVELLES², JOSÉ JOAQUÍN MUROSMOLINA ${ }^{1}$, RAMÓN CHACÓN-CUBEROS 3

${ }^{1}$ Department of Didactics of Musical, Plastic and Corporal Expression, University of Granada, Spain

${ }^{2}$ Department of Physical Education and Sport; University of Granada, Spain

${ }^{3}$ Department of Integrated Didactics, University of Huelva, Spain

\begin{abstract}
The time devoted to Physical Education classes is limited, but for many children and young people these classes are the only occasions on which they engage in physical activity and exercise. Since exercise is vital for health, it is important to use indices that provide information about the effectiveness of time invested specifically in the practice of motor activities during PE classes. We have proposed certain effectiveness indices that relate the time planned to the time actually spent in different categories: time for information, time for organisation, time for physical or motor activity and time for physical or motor activity fulfilling an objective. Various sessions of Motor Games have been evaluated, all of them corresponding to the university degree of Physical Activity and Sports Sciences. The results show that the proposed effectiveness indices could be very useful in managing time devoted to motor activity during PE lessons more effectively and in improving time planning in terms of the content of PE lessons. Key words: EFFECTIVENESS INDICES, PHYSICAL EDUCATION, MOTOR GAMES, TEACHER-TIME COMPETENCE, ALT-PE.
\end{abstract}

\section{Cite this article as:}

Valdivia-Moral, P.A., Fernández-Revelles, A.B., Muros-Molina, J.J., \& Chacón-Cuberos, R. (2018). Effectiveness indices evaluating time in physical education: Example in Motor Games. Journal of $\begin{array}{llll}\text { Human Sport and } \quad \text { Exercise, } & \text { 13(2proc), }\end{array}$ doi:https://doi.org/10.14198/jhse.2018.13.Proc2.36

Corresponding author. Department of Didactics of Musical, Plastic and Corporal Expression, University of Granada, Spain. E-mail: pvaldivia@ugr.es

Supplementary Issue: Spring Conferences of Sports Science. Costa Blanca Sports Science Week, 26-28 April 2018. Calpe. Alicante, Spain.

JOURNAL OF HUMAN SPORT \& EXERCISE ISSN 1988-5202

(c) Faculty of Education. University of Alicante

doi: 10.14198/jhse.2018.13.Proc2.36 


\section{INTRODUCTION}

In teaching, time planning and management plays a vital role in maximising the amount of time devoted directly to education and training, since the time available for classes is limited. Learning time in Physical Education classes or training sessions is especially important in that the appropriate planning and management of time can lead to improvements in the health of those attending sessions, by enabling them to spend more time exercising (Fernández-Revelles, 2003, 2008a; Fernandez-Revelles \& Delgado-Noguera, 2009, 2009; Perez Cortes, Ramirez Jimenez, \& Fernandez-Revelles, 2009; Viciana, Fernandez-Revelles, Zabala, Requena, \& Lozano, 2003).

The importance of engaging in exercise or physical or motor activity for a set number of hours per week must be borne in mind. Education systems dedicate a very limited amount of time to physical education and specifically to exercising due to the funnelling effect (Fernández-Revelles, 2003, 2008a).

Focusing on PE classes and their time restrictions, it is evident that some lesson content includes exercise or physical activity but some other content involves none, and even when physical activity is involved, it is of very low intensity.

One of the most popular types of PE class content at all educational levels, both in training sessions and in high performance, is motor games. Motor games, as closed content in their own right, with a beginning and an end, can be considered a key element within any other content related to physical or motor activity and exercise.

Therefore, Motor Games, like Physical Education sessions, can have their own temporal structure.

Different temporal structures and categories are used for analysing time in physical education classes. The most popular are System for Observing Fitness Instruction Time, which goes by the acronym SOFIT (Avresky, Geoghegan, \& Tapadiya, 1998; Capio, Sit, \& Abernethy, 2010; Cardon, Verstraete, De Clereq, \& De Bourdeaudhuij, 2004; Curtnersmith, Chen, \& Kerr, 1995; Chow, McKenzie, \& Louie, 2008, 2009; FalsonHodge \& Porretta, 2004; Faucette, McKenzie, \& Sallis, 1992; Friedman et al., 2003; Honas et al., 2008; Huang, Hogg, Zandieh, \& Bostwick, 2012; Jeng, Kim, \& Watada, 2006; Lieberman, Dunn, van der Mars, \& McCubbin, 2000; Lopez, Ochoa-Martinez, Terrazas, \& Ramirez, 2017; McClain, Abraham, Brusseau, \& Tudor-Locke, 2008; McKenzie, Sallis, \& Nader, 1992; Mersh \& Fairclough, 2010; Pope, Coleman, Gonzalez, Barron, \& Heath, 2002; P. Rowe, van der Mars, Schuldheisz, \& Fox, 2004; P. J. Rowe, Schuldheisz, \& vanderMars, 1997; Scruggs, 2007; Scruggs et al., 2003; Schuna, Lauersdorf, Behrens, Liguori, \& Liebert, 2013; Senne, Rowe, Boswell, Decker, \& Douglas, 2009; Sharpe, Forrester, \& Mandigo, 2011; Sit, McManus, McKenzie, \& Lian, 2007; Skala, Springer, Sharma, Hoelscher, \& Kelder, 2012; Stone et al., 1996; Taylor \& Yun, 2006; van der Mars, Vogler, Darst, \& Cusimano, 1998; Verstraete, Cardon, De Clercq, \& De Bourdeaudhuij, 2007; Wadsworth, Robinson, Rudisill, \& Gell, 2013) and Academic Learning Time in Physical Education, abbreviated to ALT-PE (Block \& Obrusnikova, 2007; Byra \& Coulon, 1994; Ensign, Woods, \& Kulinna, 2017; Hastie, 1994; Tempte \& Walkley, 1999; Tzetzis, Amoutzas, \& Kourtessis, 2003; Vandermars, Darst, Vogler, \& Cusimano, 1994; Wiskochil, Lieberman, Houston-Wilson, \& Petersen, 2007).

Other works also exist which are related to a different technique directly linked with play, System for Observing Children's Activity and Relationships, acronym SOCARP (Pollard, Hornby-Turner, Ghurbhurrun, \& Ridgers, 2012; Powell, Woodfield, \& Nevill, 2016; Ridgers, Fairclough, \& Stratton, 2010; Ridgers, Stratton, 
\& McKenzie, 2010; Roberts, Fairclough, Ridgers, \& Porteous, 2013; Woods, Graber, \& Daum, 2012; Woods, Graber, Daum, \& Gentry, 2015).

There are also recent studies in the field that address the issue of time devoted to learning and time in physical education classes (Hernandez \& Hernandez-Martinez, 2016; Hita \& Canto, 2017; Irigoyen, Mendieta, Negro, \& Irigoyen, 2016; Lopez et al., 2017; Martin, 2017; Moreno et al., 2017; Urrutia-Gutierrez, Otaegi-Garmendia, \& Gabilondo, 2017).

However, the research studies that serve as a reference for our work are

For motor games or PE sessions we follow the model suggested by Fernández-Revelles et al. (2017), a simple model of time structure:

- Session Time or Motor Games Time (ST): When we use a single motor game for a session or want to establish a time structure for that motor game. It is the total time devoted to that motor game or to the whole session.

- Information Time (IT): The time spent on giving information or finding out results when the participants are not practising any physical activity; if exercise is going on at the same time, this is not considered information time but time devoted to physical activity.

- Organization Time (OT): The time devoted to organising material and students, provided that the activity is not included as part of the game and physical or motor activity is also practised.

- Physical or Motor Activity Time (MT): The time devoted to physical or motor activity; that is, when participants are engaged in some form of exercise and are not stationary. If they are stationary, even if waiting for a relay or otherwise waiting to participate, the fact of not exercising during that period means that it will not count as physical activity time. It could only be considered physical activity time if the inactivity were due to a recovery period following a long spell of intensive activity, provided that time for recovery was required in order to continue.

- Physical or Motor Activity Time meeting an Objective (MTO): The time devoted to physical or motor activity that is also meeting the motor objective of the session or of the motor game.

- Motor Inactivity Time or unforeseen downtime (MIT): The time during which no physical activity takes place for some reason particular to the game, such as a participant's fall, or for an external reason such as an unauthorised person entering the game zone.

There is a measurement tool for this time structure (Fernández-Revelles, 2017), see figure 1. 


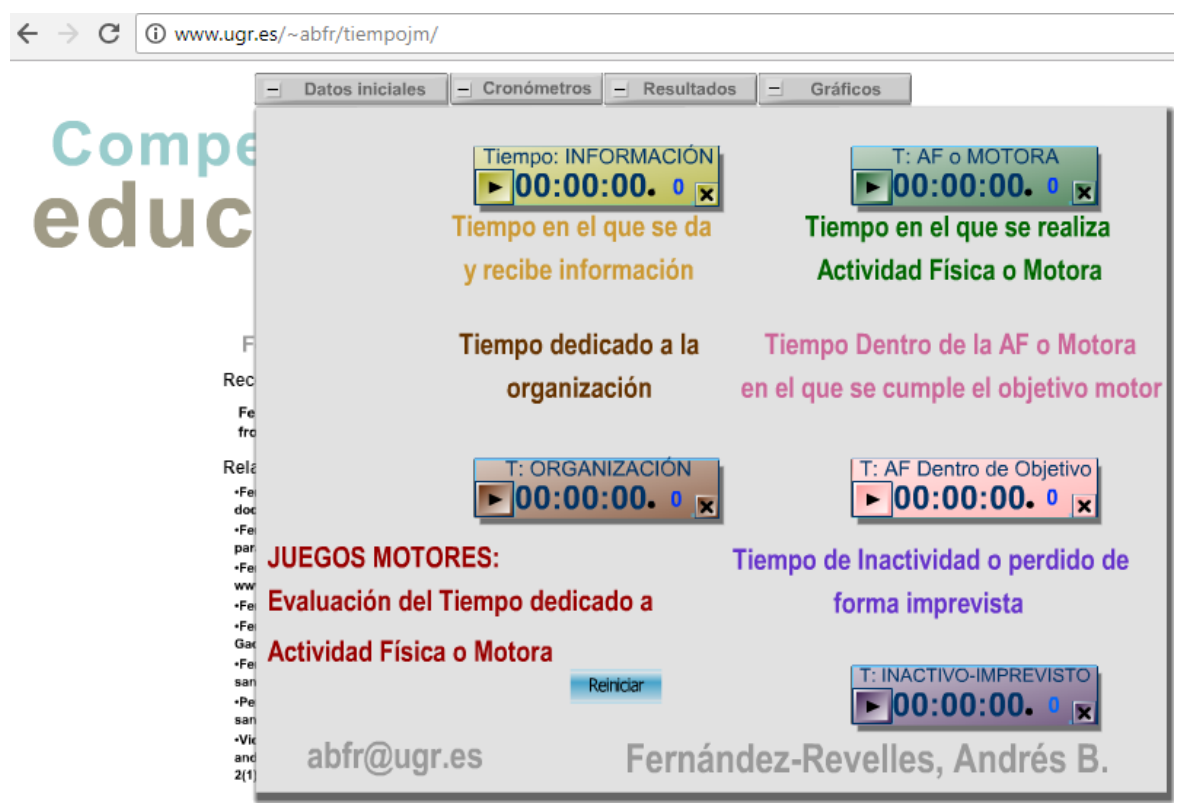

Figure 1. Application for the recording of time in motor games

By this method, the overall time of a session or of a motor game would be made up of the following times:

$S T=I T+O T+M T+M I T$

MTO would be added to MT.

For the purposes of adequate time planning and management, we would also work out the following Planned Times: P_ST, P_IT, P_OT, P_MT, P_MTO.

MIT cannot be planned since it is unforeseen.

It is also necessary to consider how to link the planned times of a session or Motor Game to its corresponding recorded times: ST, IT, OT, MT, MTO, MIT.

By relating the different categories of planned times to their corresponding recorded times we can obtain time indices showing the effectiveness of time planning for motor games.

And if we relate the different categories of registered times with overall registered time of the session we can obtain time indices showing effectiveness of time management for motor games.

The calculation of these indices will follow the patterns for PE classes established by Fernández-Revelles (2003).

\section{Objectives}

The aim of this study is to implement the time assessment of motor games and propose effectiveness indices according to planning. 


\section{MATERIALS AND METHODS}

In order to assess time we follow the guidelines established by Fernández-Revelles et al. (2017), choosing the same video of a motor game for its analysis - the motor game Tic Tac Toe (Fernández-Revelles, 2016) whose YouTube link is; https://youtu.be/lONuwPd8Wn8

The calculation of the planning indices is based on the following times:

- Planned Times:

P_ST: Planned Session Time or Planned Motor Game Time

P_IT: Planned Information Time

P_OT: Planned Organisation Time

P_MT: Planned Motor Time

P_MTO: Planned Motor Time fulfilling Objectives

- Recorded Times:

ST: Recorded Total Session or Motor Game time

IT: Recorded Information Time

OT: Recorded Organisation Time

MT: Recorded Motor Activity Time

MTO: Recorded Motor Activity Time fulfilling Objectives

MIT: Motor Inactivity Time

- Calculation of the Planning Indices:

TI: Time index:

- If ST_P $<=S T ; T I=P \_S T / S T$

- If ST_P $>S T ; T I=S T / P \_S T$

I_PI: Information Planning Index:

- If P_IT $<=I T ; I \_P I=P \_I T / I T$

- If P_IT > IT; I_PI = IT/P_IT 
O_Pl: Organisation Planning Index:

$$
\begin{aligned}
& \text { - If P_OT <= OT; O_PI = P_OT/OT } \\
& \text { - If P_OT > OT; O_PI =OT/P_OT }
\end{aligned}
$$

M_PI: Motor Planning Index:

$$
\begin{aligned}
& \text { _ } \text { If P_MT < =MT; M_PI = P_MT/MT } \\
& \text { _ } \quad \text { If P_MT > MT; M_PI = MT/P_MT }
\end{aligned}
$$

MO_PI: Motor time fulfilling an Objective Planning Index:

- If P_MTO < = MTO; MO_PI = P_MTO/MTO

- If P_MTO > MTO; MO_PI = MTO/P_MTO

MI_PI: Motor unforeseen Inactivity Index:

- $\quad$ MI_PI = MIT/ST

\section{RESULTS}

Table 1 gives the planned and recorded times of the motor game, clearly showing the discrepancies between them.

Table 1. Planned and recorded times

\begin{tabular}{lccccc}
\hline & Information & Organisation & $\begin{array}{c}\text { Physical or Motor } \\
\text { Activity }\end{array}$ & $\begin{array}{c}\text { Physical Activity } \\
\text { Objective }\end{array}$ & Inactive \\
\hline $\begin{array}{l}\text { Planned } \\
\begin{array}{l}\text { Time } \\
\text { Recorded }\end{array}\end{array}$ & $0: 02: 00$ & $0: 02: 00$ & $0: 11: 00$ & $0: 08: 00$ & \\
Time & $0: 03: 54$ & $0: 02: 59$ & $0: 05: 48$ & $0: 02: 03$ & $0: 01: 55$ \\
\hline
\end{tabular}

Table 2 shows Planning Indices in the various categories, their values ranging between 0 and $1-1$ being the value at which planned time and recorded time coincide, while values close to 0 indicate a significant difference between planned and recorded times.

Table 2. Planning indices

\begin{tabular}{cccccc} 
Information & Organisation & $\begin{array}{c}\text { Physical or } \\
\text { Motor Activity }\end{array}$ & $\begin{array}{c}\text { Physical } \\
\text { Activity } \\
\text { Objective }\end{array}$ & Inactive & Timetable \\
\hline 0.513 & 0.670 & 0.527 & 0.256 & 0.128 & 0.973 \\
\hline
\end{tabular}

\begin{tabular}{lllllll}
\hline $\begin{array}{l}\text { Planning } \\
\text { indices }\end{array}$ & 0.513 & 0.670 & 0.527 & 0.256 & 0.128 & 0.973 \\
\hline S534 & | 2018 | Proc2 | VOLUME 13 & & & & @ 2018 University of Alicante
\end{tabular}




\section{DISCUSSION}

The results indicate that motor games suffer the funneling effect just as PE classes do proportion of the time.

\section{Planning indices}

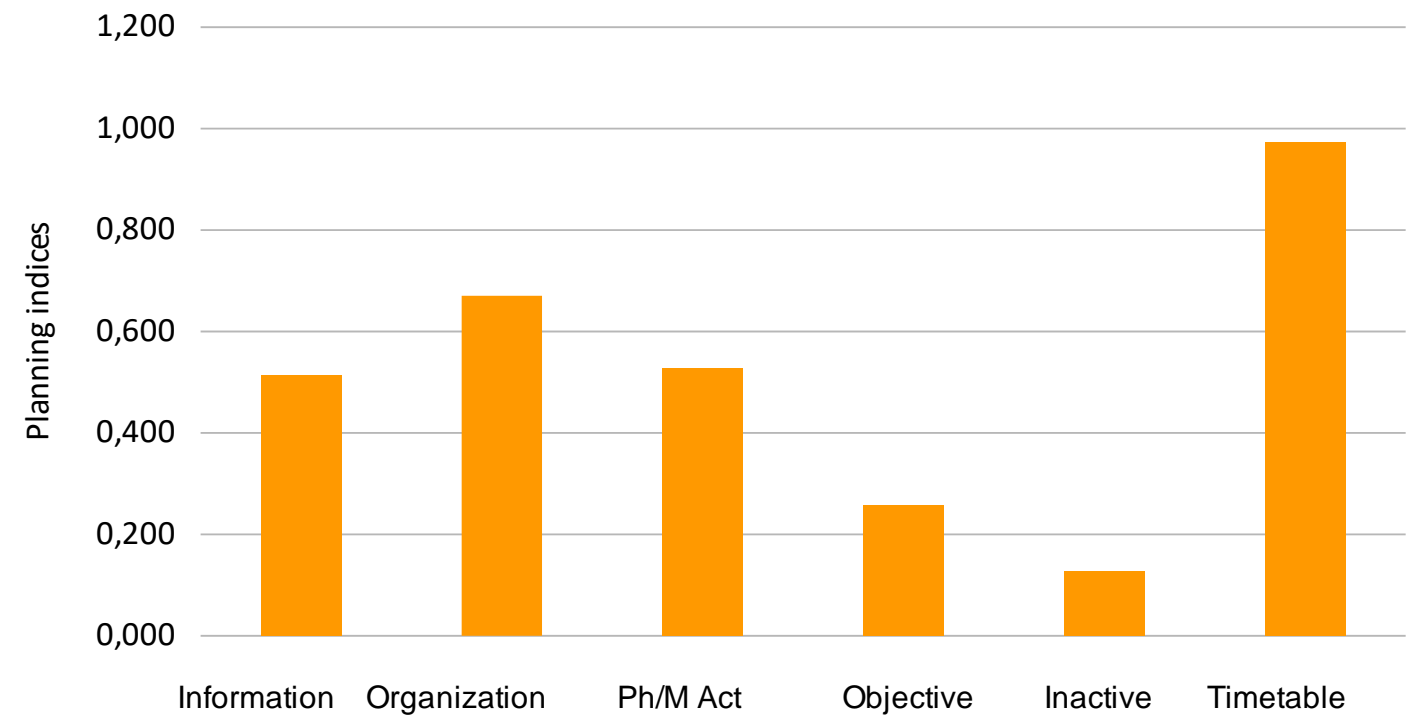

Figure 2. Planning indices

A motor game is defined as a game involving movement. In order to qualify as a motor game, a game has to meet the motor objective; thus, when planning it, one must take account of the fact that movement is required most of the time. These indices are therefore a valuable indicator of the percentage of movement performed in the motor game in relation to what was planned. As we can see in this case, the index of motor time meeting an objective is only 0,256 ; in other words, the planning in relation to the recorded motor time meeting an objective has approached a $25.6 \%$.

The timetable was observed with a timetable index of 97.3 .

\section{CONCLUSIONS}

The assessment of time in motor games has been implemented, and effectiveness indices have been suggested and calculated according to planning for each of the time categories in use.

\section{ACKNOWLEDGEMENTS}

The work on this article was carried out without funding.

\section{CONFLICT OF INTEREST}

The author has no conflicts of interest. 


\section{REFERENCES}

Avresky, D. R., Geoghegan, S. J., \& Tapadiya, P. K. (1998). A software-based fault injection tool (SOFIT). Computer Systems Science and Engineering, 13(6), 327-337.

Block, M. E., \& Obrusnikova, I. (2007). Inclusion in physical education: A review of the literature from 1995-2005. Adapted Physical Activity Quarterly, 24(2), 103-124. https://doi.org/10.1123/apaq.24.2.103

Byra, M., \& Coulon, S. C. (1994). The effect of planning on the instructional behaviors of preservice teachers. Journal Of Teaching In Physical Education, 13(2), 123-139. https://doi.org/10.1123/itpe.13.2.123

Capio, C. M., Sit, C. H., \& Abernethy, B. (2010). Physical Activity Measurement Using MTI (Actigraph) Among Children With Cerebral Palsy. Archives of Physical Medicine and Rehabilitation, 91(8), 12831290. https://doi.org/10.1016/i.apmr.2010.04.026

Cardon, G., Verstraete, S., De Clereq, D., \& De Bourdeaudhuij, I. (2004). Physical activity levels in elementary-school physical education: A comparison of swimming and nonswimming classes. Journal Of Teaching In Physical Education, 23(3), 252-263. https://doi.org/10.1123/itpe.23.3.252

Curtnersmith, M. D., Chen, W. Y., \& Kerr, I. G. (1995). Health-related fitness in secondary-school physical-education - a descriptive-analytic study. Educational Studies, 21(1), 55-66. https://doi.org/10.1080/0305569950210105

Chow, B. C., McKenzie, T. L., \& Louie, L. (2008). Children's physical activity and environmental influences during elementary school physical education. Journal Of Teaching In Physical Education, 27(1), 38-50. https://doi.org/10.1123/itpe.27.1.38

Chow, B. C., McKenzie, T. L., \& Louie, L. (2009). Physical Activity and Environmental Influences During Secondary School Physical Education. Journal Of Teaching In Physical Education, 28(1), 21-37. https://doi.org/10.1123/itpe.28.1.21

Ensign, J., Woods, A. M., \& Kulinna, P. H. (2017). Teacher Development in First-Year Physical Educators: A Comparison of Effectiveness Among Different Physical Education Teacher Education Backgrounds. Journal Of Teaching In Physical Education, 36(4), 455-466. https://doi.org/10.1123/itpe.2016-0105

Falson-Hodge, J., \& Porretta, D. L. (2004). Physical activity levels of students with mental retardation and students without disabilities. Adapted Physical Activity Quarterly, 21(2), 139-152. https://doi.org/10.1123/apaq.21.2.139

Faucette, N., McKenzie, T. L., \& Sallis, J. F. (1992). Self-contained versus team teaching - an analysis of a physical-education intervention by classroom teachers. Journal Of Teaching In Physical Education, 11(3), 268-287. https://doi.org/10.1123/itpe.11.3.268

Fernández-Revelles, A. B. (2003). Efectos del conocimiento de resultados de los índices temporales de eficacia sobre la competencia docente Tiempo. (Tesis), Universidad de Granada, Granada.

Fernández-Revelles, A. B. (2008a). El tiempo en la clase de educación física: la competencia docente tiempo. Deporte y actividad física para todos, 4, 102-120.

Fernández-Revelles, A. B. (2008b). Tiempo de Educación Física, Competencia Docente. from www.ugr.es/local/abfr/TESIS_Andres_B_Fdez_Revelles/index_abierto2.html

Fernández-Revelles, A. B. (2008c). Tiempo en Educación Física, Competencia Docente. Granada: Fernández Revelles, Andrés Bernardo.

Fernández-Revelles, A. B. (2013, 12/07/2013). Tiempo de Educación Física, Competencia Docente. Retrieved 12/07/2013, from http://www.ugr.es/local/abfr/tiempo.html

Fernández-Revelles, A. B. (Producer). (2016, Septiembre 2017). 3 en raya 00154 Juegos Motores. juegos_motores. [Video file] Retrieved from https://youtu.be/lONuwPd8Wn8 
Fernández-Revelles, A. B. (2017). Time in Motor Games (Tiempo en Juegos Motores). RRID:SCR_015819. http://www.ugr.es/local/abfr/tiempoim

Fernandez-Revelles, A. B., \& Delgado-Noguera, M. A. (2009). Physical activity among children of different culture and gender. Gaceta sanitaria, 23, 107-108.

Fernández-Revelles, A. B., \& Delgado-Noguera, M. A. (2009). Increase physical activity time of children in physical education classes. Gaceta sanitaria, 23, 107-107.

Fernández-Revelles, A. B., Viciana-Garófano, V., Espejo-Garcés, T., \& González-Valero, G. (2017). Methdology for planning and time management in Motor Games. Sports Science 3.0, 1(1), 44-70. doi: http://hdl.handle.net/10481/50754

Friedman, S. L., Belsky, J., Booth, C., Bradley, R. E., Brownell, C. A., Campbell, S. B., . . Yo, N. S. E. C. C. (2003). Frequency and intensity of activity of third-grade children in physical education. Archives of Pediatrics \& Adolescent Medicine, 157(2), 185-190. https://doi.org/10.1001/archpedi.157.2.185

Hastie, P. A. (1994). Selected teacher behaviors and student alt-pe in secondary-school physicaleducation. Journal Of Teaching In Physical Education, 13(3), 242-259. https://doi.org/10.1123/itpe.13.3.242

Hernandez, J. A., \& Hernandez-Martinez, A. (2016). Motor games sensitizers and its effect on attitudes towards disability shown by future teachers of Physical Education. Sportis-Scientific Technical Journal of School Sport Physical Education and Psychomotricity, 2(1), 93-106.

Hita, F. J. M., \& Canto, E. G. (2017). Influence of bilingualism on engagement motor time in Physical Education. Retos-Nuevas Tendencias En Educacion Fisica Deporte Y Recreacion(32), 178-182.

Honas, J. J., Washburn, R. A., Smith, B. K., Greene, J. L., Cook-Wiens, G., \& Donnelly, J. E. (2008). The System for Observing Fitness Instruction Time (SOFIT) as a Measure of Energy Expenditure During Classroom-Based Physical Activity. Pediatric Exercise Science, 20(4), 439-445. https://doi.org/10.1123/pes.20.4.439

Huang, S. Y., Hogg, J., Zandieh, S., \& Bostwick, S. B. (2012). A Ballroom Dance Classroom Program Promotes Moderate to Vigorous Physical Activity in Elementary School Children. American Journal of Health Promotion, 26(3), 160-165. doi: 10.9278/ajhp.090625-QUAN-203

Irigoyen, J. Y., Mendieta, A. V., Negro, J. R., \& Irigoyen, L. Y. (2016). Commitment motor time in primary education first and second cycle physical education sessions. Sportis-Scientific Technical Journal of School Sport Physical Education and Psychomotricity, 2(2), 239-253. https://doi.org/10.17979/sportis.2016.2.2.1447

Jeng, D. J. F., Kim, I., \& Watada, J. (2006). Bio-soft computing approach to elevator dispatching problem. Los Alamitos: leee Computer Soc. https://doi.org/10.1109/ICICIC.2006.57

Lieberman, L. J., Dunn, J. M., van der Mars, H., \& McCubbin, J. (2000). Peer tutors' effects on activity levels of deaf students in inclusive elementary physical education. Adapted Physical Activity Quarterly, 17(1), 20-39. https://doi.org/10.1123/apaq.17.1.20

Lopez, J. A. H., Ochoa-Martinez, P. Y., Terrazas, J. C. G., \& Ramirez, J. R. G. (2017). Duration, intensity and context of Physical Education classes taught by teachers and undergraduate students. SportisScientific Technical Journal of School Sport Physical Education and Psychomotricity, 3(1), 577-597. https://doi.org/10.17979/sportis.2017.3.1.1723

Martin, D. S. (2017). Moderate-vigorous physical activity levels of adolescents of the municipality of Soria. Sportis-Scientific Technical Journal of School Sport Physical Education and Psychomotricity, 3(1), 100-122. https://doi.org/10.17979/sportis.2017.3.1.1738

McClain, J. J., Abraham, T. L., Brusseau, T. A., \& Tudor-Locke, C. (2008). Epoch Length and Accelerometer Outputs in Children: Comparison to Direct Observation. Medicine and Science in Sports and Exercise, 40(12), 2080-2087. https://doi.org/10.1249/MSS.0b013e3181824d98 
McKenzie, T. L., Sallis, J. F., \& Nader, P. R. (1992). SOFIT - System for Observing Fitness Instruction Time. Journal Of Teaching In Physical Education, 11(2), 195-205. https://doi.org/10.1123/itpe.11.2.195

Mersh, R., \& Fairclough, S. J. (2010). Physical activity, lesson context and teacher behaviours within the revised English National Curriculum for Physical Education: A case study of one school. European Physical Education Review, 16(1), 29-45. https://doi.org/10.1177/1356336X10369199

Moreno, P. J. F., Salazar, C. M., Figueroa, J. A. G., Villa, Y. B., Gonzalez, O. V., Rivera, J. U. V., \& Valdivia, J. E. D. (2017). The effective time measurement of physical education and its impact on caloric expenditure at primary schoolchildren level Municipality of Colima, Mexico. Sportis-Scientific Technical Journal of School Sport Physical Education and Psychomotricity, 3(1), 34-49. https://doi.org/10.17979/sportis.2017.3.1.1766

Perez Cortes, A. J., Ramirez Jimenez, V. P., \& Fernandez-Revelles, A. B. (2009). Health status and heart response in schools. Gaceta sanitaria, 23, 306-306.

Pollard, T. M., Hornby-Turner, Y. C., Ghurbhurrun, A., \& Ridgers, N. D. (2012). Differences between 911 year old British Pakistani and White British girls in physical activity and behavior during school recess. Bmc Public Health, 12, 8. https://doi.org/10.1186/1471-2458-12-1087

Pope, R. P., Coleman, K. J., Gonzalez, E. C., Barron, F., \& Heath, E. M. (2002). Validity of a revised system for observing fitness instruction time (SOFIT). Pediatric Exercise Science, 14(2), 135-146. https://doi.org/10.1123/pes.14.2.135

Powell, E., Woodfield, L. A., \& Nevill, A. A. M. (2016). Children's physical activity levels during primary school break times: A quantitative and qualitative research design. European Physical Education Review, 22(1), 82-98. https://doi.org/10.1177/1356336X15591135

Ridgers, N. D., Fairclough, S. J., \& Stratton, G. (2010). Variables associated with children's physical activity levels during recess: the A-CLASS project. International Journal of Behavioral Nutrition and Physical Activity, 7, 8. https://doi.org/10.1186/1479-5868-7-74

Ridgers, N. D., Stratton, G., \& McKenzie, T. L. (2010). Reliability and Validity of the System for Observing Children's Activity and Relationships During Play (SOCARP). Journal of Physical Activity \& Health, 7(1), 17-25. https://doi.org/10.1123/ipah.7.1.17

Roberts, S. J., Fairclough, S. J., Ridgers, N. D., \& Porteous, C. (2013). An observational assessment of physical activity levels and social behaviour during elementary school recess. Health Education Journal, 72(3), 254-262. https://doi.org/10.1177/0017896912439126

Rowe, P., van der Mars, H., Schuldheisz, J., \& Fox, S. (2004). Measuring students' physical activity levels: Validating SOFIT for use with high-school students. Journal Of Teaching In Physical Education, 23(3), 235-251. https://doi.org/10.1123/itpe.23.3.235

Rowe, P. J., Schuldheisz, J. M., \& vanderMars, H. (1997). Validation of SOFIT for measuring physical activity of first- to eighth-grade students. Pediatric Exercise Science, 9(2), 136-149. https://doi.org/10.1123/pes.9.2.136

Scruggs, P. W. (2007). A comparative analysis of pedometry in measuring physical activity of children. Medicine and Science in Sports and Exercise, 39(10), 1837-1846. https://doi.org/10.1249/mss.0b013e318126c1aa

Scruggs, P. W., Beveridge, S. K., Eisenman, P. A., Watson, D. L., Shultz, B. B., \& Ransdell, L. B. (2003). Quantifying physical activity via pedometry in elementary physical education. Medicine and Science in Sports and Exercise, 35(6), 1065-1071. https://doi.org/10.1249/01.MSS.0000069748.02525.B2

Schuna, J. M., Lauersdorf, R. L., Behrens, T. K., Liguori, G., \& Liebert, M. L. (2013). An Objective Assessment of Children's Physical Activity During the Keep It Moving! After-School Program. Journal of School Health, 83(2), 105-111. https://doi.org/10.1111/josh.12005 
Senne, T., Rowe, D., Boswell, B., Decker, J., \& Douglas, S. (2009). Factors associated with adolescent physical activity during middle school physical education: A one-year case study. European Physical Education Review, 15(3), 295-314. https://doi.org/10.1177/1356336X09364722

Sharpe, E. K., Forrester, S., \& Mandigo, J. (2011). Engaging Community Providers to Create More Active After-School Environments: Results From the Ontario CATCH Kids Club Implementation Project. Journal of Physical Activity \& Health, 8, S26-S31. https://doi.org/10.1123/jpah.8.s1.s26

Sit, C. H. P., McManus, A., McKenzie, T. L., \& Lian, J. (2007). Physical activity levels of children in special schools. Preventive Medicine, 45(6), 424-431. https://doi.org/10.1016/j.ypmed.2007.02.003

Skala, K. A., Springer, A. E., Sharma, S. V., Hoelscher, D. M., \& Kelder, S. H. (2012). Environmental Characteristics and Student Physical Activity in PE Class: Findings From Two Large Urban Areas of Texas. Journal of Physical Activity \& Health, 9(4), 481-491. https://doi.org/10.1123/jpah.9.4.481

Stone, E. J., Osganian, S. K., McKinlay, S. M., Wu, M. C., Webber, L. S., Luepker, R. V., . . Elder, J. P. (1996). Operational design and quality control in the CATCH multicenter trial. Preventive Medicine, 25(4), 384-399. https://doi.org/10.1006/pmed.1996.0071

Taylor, C. A., \& Yun, J. (2006). Psychometric properties of two systematic observation techniques for assessing physical activity levels in children with mental retardation. Pediatric Exercise Science, 18(4), 446-456. https://doi.org/10.1123/pes.18.4.446

Tempte, V. A., \& Walkley, J. W. (1999). Academic Learning Time-Physical Education (ALT-PE) of students with mild intellectual disabilities in regular Victorian schools. Adapted Physical Activity Quarterly, 16(1), 64-74. https://doi.org/10.1123/apaq.16.1.64

Tzetzis, G., Amoutzas, K., \& Kourtessis, T. (2003). A multidimensional analysis of teacher and students interactions and physical activity in physical education classes. Journal of Human Movement Studies, 44(4), 339-351.

Urrutia-Gutierrez, S., Otaegi-Garmendia, O., \& Gabilondo, J. A. A. (2017). Motor Competence, Perceived Motor Competence and Physical and Sport Practice among Adolescents. Sportis-Scientific Technical Journal of School Sport Physical Education and Psychomotricity, 3(2), 256-271. https://doi.org/10.17979/sportis.2017.3.2.1908

van der Mars, H., Vogler, B., Darst, P., \& Cusimano, B. (1998). Students' physical activity levels and teachers' active supervision during fitness instruction. Journal Of Teaching In Physical Education, 18(1), 57-75. https://doi.org/10.1123/itpe.18.1.57

Vandermars, H., Darst, P., Vogler, B., \& Cusimano, B. (1994). Active supervision patterns of physicaleducation teachers and their relationship with student behaviors. Journal Of Teaching In Physical Education, 14(1), 99-112. https://doi.org/10.1123/jtpe.14.1.99

Verstraete, S. J. M., Cardon, G. M., De Clercq, D. L. R., \& De Bourdeaudhuij, I. M. M. (2007). Effectiveness of a two-year health-related physical education intervention in elementary schools. Journal Of Teaching In Physical Education, 26(1), 20-34. https://doi.org/10.1123/jtpe.26.1.20

Viciana, J., Fernandez-Revelles, A. B., Zabala, M., Requena, B., \& Lozano, L. (2003). Computerized application for analysing the time and instructional parameters in sport coaching and physical education teaching. International Journal of Computer Science in Sport, 2(1), 189-190.

Wadsworth, D. D., Robinson, L. E., Rudisill, M. E., \& Gell, N. (2013). The Effect of Physical Education Climates on Elementary Students' Physical Activity Behaviors. Journal of School Health, 83(5), 306313. https://doi.org/10.1111/josh.12032

Wiskochil, B., Lieberman, L. J., Houston-Wilson, C., \& Petersen, S. (2007). The effects of trained peer tutors on the physical education of children who are visually impaired. Journal of Visual Impairment \& Blindness, 101(6), 339-350. 
Woods, A. M., Graber, K., \& Daum, D. (2012). Children's Recess Physical Activity: Movement Patterns and Preferences. Journal Of Teaching In Physical Education, 31(2), 146-162. https://doi.org/10.1123/jtpe.31.2.146

Woods, A. M., Graber, K. C., Daum, D. N., \& Gentry, C. (2015). Young School Children's Recess Physical Activity: Movement Patterns and Preferences. Journal Of Teaching In Physical Education, 34(3), 496-516. https://doi.org/10.1123/jtpe.2014-0048

\section{(c) $(9)\left(\Theta_{\mathrm{EY}}\right.$}

This title is licensed under a Creative Commons Attribution-NonCommercial-NoDerivs 4.0 Unported License. 